\section{JTI}

JOURNAL OF

TRAUMA AND INJURY

\title{
Trauma Surgeons: Heroes of a Moment
}

\author{
Kun Hwang, M.D., Ph.D. \\ Department of Plastic Surgery, Inha University College of Medicine, Incheon, Korea
}

Received: January 13, 2021

Accepted: February 5, 2021

\section{Correspondence to}

Kun Hwang, M.D., Ph.D.

Department of Plastic Surgery, Inha University College of Medicine, 27

Inhang-ro, Jung-gu, Incheon 22332, Korea

Tel: +82-32-890-3514

Fax: +82-32-890-2918

E-mail: jokerhg@inha.ac.kr http://www.jtraumainj.org
Because of COVID-19, it has not been possible for me to attend mass recently. Instead, I listen to sermons and hymns online. My favorite hymn is "The Lily of the Valley": "He's the 'Lily of the Valley', the Bright and Morning Star/He's the fairest of ten thousand to my soul".

This hymn was written by William Charles Fry (1837-1882) for the Salvation Army and first published in 1881. The words were arranged to the music of "The Little Old Log Cabin in the Lane". It became a gospel standard and appears in almost all Protestant hymnals. It is generally understood that Fry took the term "Lily of the Valley" from the book of Song of Solomon 2:1 ("I am the rose of Sharon, the lily of the valley").

However, the French novelist and playwright Honoré de Balzac (1799-1850) wrote a novel of same name about a half century before Fry (1835). Balzac wrote this novel, dealing with themes of emotionally vibrant but never consummated affection, and titled it Lily of the Valley, representing the character of Henriette de Mortsauf.

Touched by this novel portraying the theme of affection, I read Balzac's other short stories and found a very interesting story about a great surgeon: "The Atheist's Mass" (Fig. 1). The protagonist, Desplein, is a successful surgeon and an atheist. One day his former assistant Bianchon sees Desplein going into a church and alone attending a mass. Bianchon questions the priest and finds that Desplein attends a mass at the church four times a year, which he himself pays for. Years later, Bianchon again sees Desplein going into the church and questions Desplein about it. Desplein explains that the mass is in memory of a water carrier named Bourgeat, who was his friend and father figure. When Desplein was a poor medical student, Bourgeat helped to pay for Desplein's education, and did menial tasks like cutting wood. After Desplein became successful, he bought Bourgeat a horse and cart for his water-carrying work. After Bourgeat's death, knowing that Bourgeat was a devout Catholic, Desplein decided to have four masses a year for him at church.

In this novel, Balzac defines the glory of a surgeon as follows: "The glory of a surgeon is like that of an actor: they live only so long as they are alive, and their talent leaves no trace when they are gone. Actors and surgeons, like great singers too, like the executants who by their performance increase the power of music tenfold, are all the (http://creativecommons.org/licenses/by-nc/4.0/) which permits unrestricted noncommercial use, distribution, and reproduction in any medium, provided the original work is properly cited. 


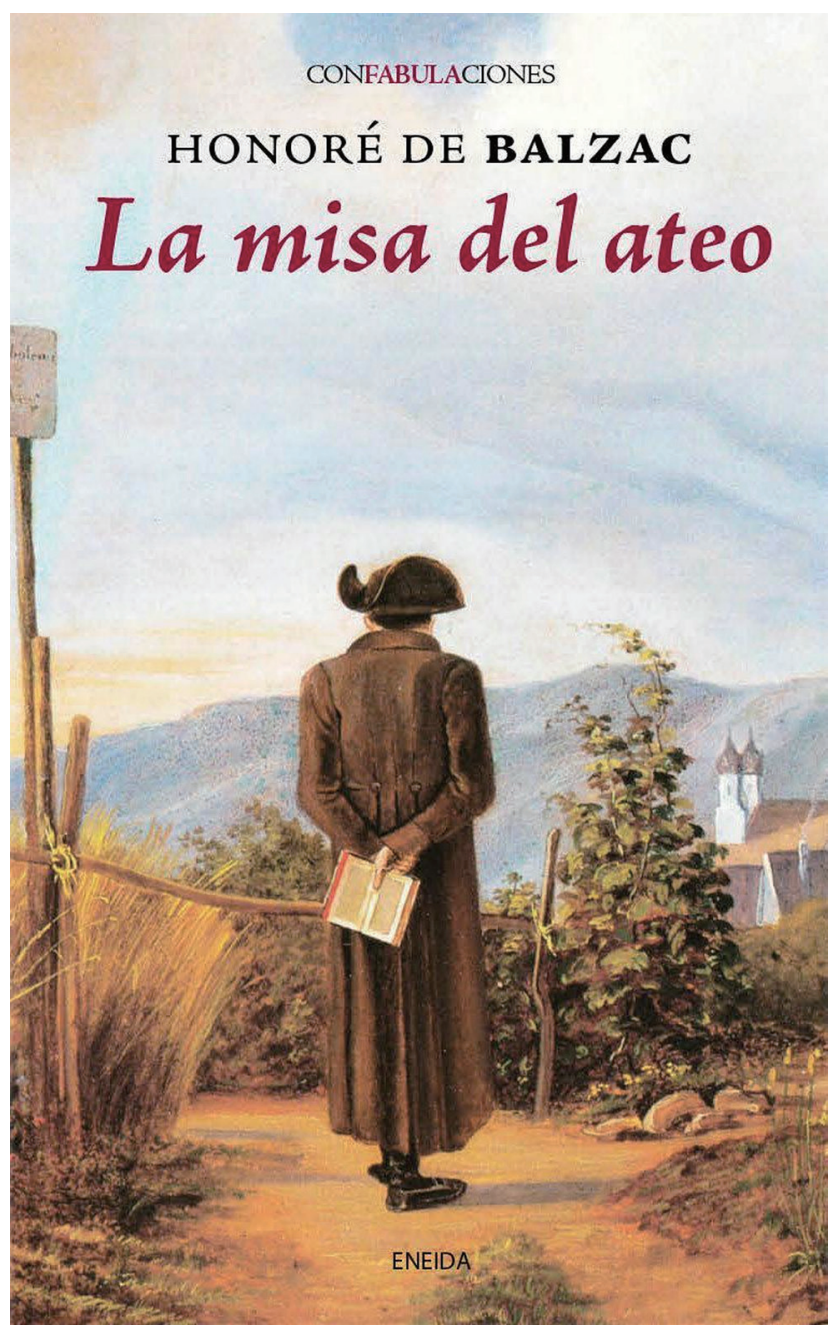

Fig. 1. The atheist's mass and other stories (La Misa del ateo, 2013, Spanish Edition) written by Honoré de Balzac (1799-1850). Madrid: Edtorial Eneida. heroes of a moment".

When trauma patients arrive at a trauma center, we make decisions and move fast like actors. When a trauma victim's life is saved and stabilized, our performance is over. We are the heroes of a moment like actors. As a trauma surgeon, I completely agree with Balzac that surgeons live only so long as they are alive and their talent leaves no trace when they are gone. Like a "Lily of the Valley", and the "Bright and Morning Star", we trauma surgeons give "every care on them to roll".

\section{ACKNOWLEDGEMENTS}

This study was supported by a grant from National Research Foundation of Korea (NRF-2020R1I1A2054761). 